Mansoura University

Faculty of Education

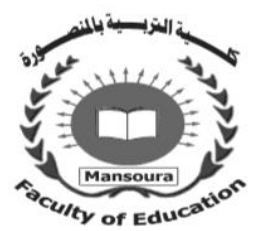

\title{
Developing EFL Speaking Skills through using a Beyond-Constructivism Paradigm Based Program
}

\author{
$\mathscr{B} y$ \\ Amira Mohamed El-Saeid Ibrahim El-Fouly \\ A Teacher of English at Delta International language schools
}

\section{Supervised by}

Prof. Badran A. Hassan

Professor of Curriculum \& Instruction (TEFL)

Faculty of Education Mansoura University
Dr. Samah Rizk Hassan

Assistant professor of Curriculum \& Instruction (TEFL)

Faculty of Education

Mansoura University

Journal Of The Faculty Of Education-Mansoura University

No. 112 -Oct .2020 


\title{
Developing EFL Speaking Skills through using a Beyond- Constructivism Paradigm Based Program
}

\author{
Amira Mohamed El-Saeid Ibrahim El-Fouly
}

\begin{abstract}
The aim of this study was to develop primary stage pupils' EFL speaking skills through using a beyond-constructivism paradigm based program proposed by the researcher. The program integrated listening, speaking and technology. To fulfill the purpose of the study, the following instruments were constructed; a speaking skills checklist to determine the most important speaking skills for primary stage pupils, a speaking skills test for assessing the performance of the 6th grade primary stage pupils with a rubric to score the test. Different listening and speaking techniques such as listening tracks, online videos, multimedia reflective activities, etc. were incorporated in the program. The study adopted the quasi-experimental design using a pre-post two independent groups design. Two intact classes were selected randomly to represent the experimental and the control groups $(N=70)$. The program lasted for 6 weeks (2 sessions per week, $45 \mathrm{~min}$. each). The study results revealed that there was a statistically significant difference at 0.01 level between the mean scores of the control and experimental groups on the post test in favor of the post one. The results also revealed that the proposed beyond constructivism paradigm program proved to be effective in developing sixth grade primary pupils' EFL speaking skills. Finally, it was recommended that further research should be conducted related to using programs based on a beyond constructivism paradigm and developing preparatory stage pupils' speaking skills.
\end{abstract}




\section{1- Introduction:}

Language is a means of communication; learners use language in transmitting messages or information and expressing their emotions and thoughts. Language is used to state everyone's hopes, ambitions, and thoughts. Teaching English as a foreign language in technology-rich environments strengthen language learning and expedite communication. The scope of changes in learning enabled by technologies raises. Consequently, there is a need to expand the repertoire of theories and research approaches (Bell, 2011).

The speaking skill is as vital as other language skills (i.e., reading, writing, or listening), clearly they appear together in every English class, even in the EFL context. Therefore, there is a necessity to have clear understanding involved in speech (Widiastuti, 2008). The speaking skill could be considered the most important one among the four language skills. persons who know a language are referred to as 'speakers of this language', as if speaking integrated all other types of skills, and many, if not most foreign language learners are mainly interested in learning to speak (Ur, 2006).

Erin (2017) stated that speaking skill lays the foundation for the other language skills which pupils will need to develop; therefore teachers in EFL classes have to apply various techniques to develop the speaking skill. Pupils learn through speaking, yet learning how to talk is often undervalued in the classroom (Alexander, 2008). Speaking can be used to enhance understanding and facilitate deeper thinking.

Speaking fluency means the ability to converse with others, much more than the ability to write, read or comprehend oral language. A large percentage of world's language learners study English in order to develop proficiency in speaking. Speaking is more than free conversation because communication involves expression, interpretation and negotiation of meaning. Speaking can include simple question-and-answer, role playing, developed narration and problem solving (Grubar, 2005).

Beyond constructivism paradigm (Navigationism) aims to go beyond the limits of constructivism and avoid the shortcomings constructivism encountered. Brown (2006) states that in this novel learning paradigm, the emphasis will be on knowledge navigation. A central aim of present-day education is to prepare pupils for the emergent knowledge society through appropriate pedagogical practices (Kozma, 2003). Pupils use this new technology to gather, organize, analyze information and then use the 
information to solve problems, for higher-order thinking skills than merely learning basic skills.

According to Blake (2016), speaking in the second language can be assisted by technology in two modes, Computer Mediated Communication (CMC) and tutorial Computer Assisted Language Learning (CALL). These types of software programs ask students to compare their own audio recordings with those of native speakers of diverse accents. One obvious drawback of this type of exercise for improving second language speech is the lack of any feedback.

For instance, pupils need a complete chance to practice in the full range of communication roles. Consequently, there is a need for changing teacher roles to become coaches and mentors instead of being talkers and knowledge holders.

Brown (2006) indicated that learning processes and learning paradigms are still very much founded in a content-driven and knowledge production paradigm. The rapid developments in information and communication technologies already have and will continue to have a profound impact on information processing, knowledge production and learning paradigms. One needs to acknowledge the increasing role and impact of technology on education and training. One has already experienced enormous challenges in coping with the current overflow of available information.

\section{Review of literature}

Educators have moved speedily in the area of educational technology. Whether they are involved in higher education, secondary education, elementary education or special education (Turner, 2005). Scott (2015) stated that as a result of the persistent use of digital and mobile technologies, most pupils today are natural investigators, researchers and synthesizers of information. These skills can be put to strong use in the classroom to unlock learners' engagement. Technologies in which learners are already well versed are an effective way to support independent and enquiry-based learning, and to allow for instant and reflective forms of assessment.

According to Shapiro and Niederhauser (2004), navigation is an important form that differentiates hypertext learning from the learning of traditional text. Learners are growing up with the internet as an integral part of their everyday life. Also, the use of the internet cannot be ignored in the classroom because it is a part of the learners' life. Therefore, it is necessary 
that EFL teachers should use the internet and be able to make use of it in the classroom in order to prepare learners for their future as best as they can.

Schaeffer, Glaser, Meister \& Strubing, (2006) state that Beyond constructivism is a new concept, partly because this is yet beyond something. In other words, constructivism will not disappear in teaching or learning process. On the contrary, it will continue. Therefore, constructivists should consider all the shortcomings of constructivism and move beyond it. This future scenario will have a significant impact on information processing (including sense making) and most definitely on our learning processes and learning paradigms that are currently still very much founded in a content and knowledge production paradigm ( Brown,2006).

According to Brown (2015) learning paradigms continuously evolve as our understanding of our teaching and learning practice develops. During the last few decades of the previous century, the role of the teacher first shifted from teaching to learning facilitation. More recently this role shifted towards "facilitated and supported enquiry. Therefore contemporary educational paradigms focus not only on the production of knowledge but are beginning to focus more and more on the effective application, integration, and manipulation of existing information and knowledge.

\section{Paradigm Shifts in Education over Recent Decades}

According to Tom H. Brown (2005), the most prominent paradigm shifts in education during the 20th century are discussed briefly as follows:

\section{A. Reproductive learning vs. productive learning}

Learner's achievement was measured with their ability to reproduce subject, in other words, memorizing the content transferred to them. With the affirmation on productive learning, it is rather about the application of knowledge and skills, what the learners can do after completing the learning process. Achievement is measured against the productive contribution a learner can make, instead of what the learner can reproduce.

\section{B. Behaviourism vs. constructivism}

Agreeing to a behavioristic view of learning, a learning result is specified by a change in the behavior of a learner (Venezky and Osin, 1991). Also, as constructivist view, learning is seen as the individualized construction of meanings by the learner (Cunningham, 1991). Neither of these views can be regarded as entirely right or wrong. Thus, there is a necessary to know that constructivism is presently accepted as the more relevant of the two and that education policies, education models and education practices focus on constructivism.

\section{C.Teacher-centered vs. learner-centered}


In a learner-centered approach, the learning environment is designed according to the needs and capabilities of the specific learner group and the learner accepts the overall responsibility for his/her own learning. Teachercenteredness is identified by a view that the teacher is the primary source of knowledge for learners. In a teacher-centered paradigm the teacher accepts this responsibility.

For this reason, self-directed learning plays such an important role in effective learner- centered education systems. The focus shifts towards the instructional design of a conducive learning environment, in which effective learning can take place.

\section{D.Teaching-centered vs. learning-centered}

Education activities were carried out and planned from a teaching view which is based on the preferable teaching methods to transfer the content to the learners. In the new paradigm, education activities are planned and executed from a learning view. Thus, the focus is on how the learning, which should take place, can be optimized. In general, there must be a conversion from a teaching to a learning culture. (Arnold in Peters, 1999).

E.Teaching vs. learning facilitation

Teaching is seen as an activity that relates to the "transfer of content" within a teaching-centered education paradigm. The principle of learning facilitation pursues a learning-centered education paradigm. Learning facilitation has to do with strategies and activities that focus on optimizing the learner's learning process. The role of the instructor, therefore, changes to one of learning facilitator.

\section{F.Content-based vs. outcomes-based}

A content-based approach to education is characterized by activities that focus on subject content. In contrast, an outcomes-based approach to education focuses on the learning outcomes to be reached by the learners.

\section{Content-based evaluation vs. outcomes-based assessment}

Content-based evaluation follows a reproductive view of learning where a learner's achievement is measured by the quality and quantity of content. In contrast, outcomes-based assessment refers to a productive view of learning where a learner's achievement is measured by the level and extent to which learning outcomes are mastered.

\section{Exploring the Beyond Constructivism Paradigm}

The advancements in technology are not only enabling the transformation in learning, but mandating it. Today, students can construct their own global learning institute for themselves. Humes,(2013,p.2) 
affirmed that; "Through technology, if you are good, you can create your own global academy, because you can learn from anywhere you like, from anybody you like".

Contemporary educational paradigms focus not only on the production of knowledge, but they are also beginning to focus more and more on the effective application, integration and manipulation of existing information and knowledge. A new type of literacy is also emerging, namely information navigation.

Restak (2003) posited that, within the modern age, we must be able to process information rapidly, function amidst chaotic surroundings, always remain prepared to shift quickly from one activity to another and redirect attention between competing tasks without losing time. A new type of literacy emerged during the turn of the century, namely information navigation.

According to Barber, Donnelly and Rizvi (2013), students should seek to learn and practice the skills associated with being innovative. "They should seek to be on innovative teams, in innovative organizations and part of an innovative society as these are the places where they will grow and develop the skills needed to be globally competitive" (p.65). Brown(2015) argued that navigationist skills will provide the essential foundation for innovation in the knowledge era.

\section{Reasons for Going Beyond Constructivism}

Constructivism has become an important scientific paradigm in the social study of science and technology. The notion that scientific facts and technological artifacts result from processes of social construction is the major scientific innovation of the preceding decades in the sociology of science and technology. With constructivism being the established paradigm in this field of research, what comes next? What comes after constructivism in science and technology studies? The contributions of Science, Technology and Innovation Studies suggest different answers to these questions which can roughly be subsumed under the three headings "Spelling out Constructivism", "Adding Disregarded Aspects", and "Going beyond Constructivism" (Pickering, 2005.(

Mayer (2003) argued that the premise underlying the learner-centered approach is that "multimedia designs that are consistent with the way the human mind works are more effective in fostering learning than those that are not" (p. 10). No doubt that constructivism enhance EFL teaching and learning process but there is a need to engage pupils in more enriched environment. This future scenario will have a significant impact on 
information processing (including sense making) and most definitely on our learning processes and learning paradigms that are currently still very much founded in a content and knowledge production paradigm ( Brown,2006).

\section{Speaking Skills}

Speaking is very important because it is seen as a vehicle to link individuals to the society. Pupils who are very good English speakers can figure out what they believe and where they stand on issues (Hayriye, 2006). In addition, oral language is a powerful learning tool. It shapes, modifies, extends and organizes thought. In the case of speaking oral interaction is important for an effective teaching-learning process.

Realizing the high importance of speaking skill in EFL classrooms, it is very important to find and use the best instructional methods, materials, activities, media, and other requirements that will help the pupils master speaking skill. However, although a great number of studies aiming to help learners master speaking skill has been conducted, many EFL learners still find speaking very difficult to master.

\section{Components of the speaking skills}

As Brown (2005) indicated, the speaking sub-skills are identified as fluency, pronunciation, grammar and vocabulary.

\section{Fluency:}

Fluency is related to using all speaking skills in the context of the time-bound nature of speaking. It relies on the speakers' ability to use facilitation skills (fillers, lexical phrases, ellipsis etc.) and comprehensive skills (self- correction, rephrasing, or repeating) to cope with ongoing fast communication (Segawitz, 2000).

\section{Pronunciation}

Widiastuti (2008) stated that pronunciation is the way for students' to produce clearer language when they speak. It deals with the phonological process that refers to the component of a grammar made up of the elements and principles that determine how sounds vary and pattern in a language.

\section{Grammar}

Grammar is needed for pupils to arrange a correct sentence in conversation. Grammar plays an essential role in language learning. The usefulness of grammar is also to learn the accurate way to attain proficiency in a language oral and in a written form.

\section{Vocabulary}

One cannot communicate effectively or express their ideas both in oral or written forms if they do not have sufficient vocabulary. So, vocabulary 
means the appropriate diction which is used in communication (Widiastuti, 2008).

\section{Strategies for developing speaking skills Online role-playing}

Online role-play, as distinct from simulations or games, appears to be of particular value when learners are required to develop skills in interpersonal interaction (Russell\&Shepherd, 2010). Role-play, whether online or in-person, has been acknowledged as a constructivist activity because it employs a learner-centered, experiential and collaborative approach, and incorporates reflective processes as a key strategy.

\section{Communicative games}

Communicative game is a set of well-designed activities that can stimulate learners' interaction in the classroom. These games require them to take part actively in classroom by speaking and writing in order to express their own point of view or give information. More than that, pupils' confidence will be automatically formed due to its concept in building habits of interaction. Game means "an activity with rules, a goal and an element of fun. In addition, game is "an activity in which the learners play and usually interact with others" (Wright, 2006)

\section{Information gap}

In this activity, students are supposed to be working in pairs. One student will have the information that anther partner does not have and the partners will share their information. Information gap activities serve many purposes such as solving a problem or collecting information. Also, each partner plays an important role because the task cannot be completed if the partners do not provide the information the others need. These activities are effective because everybody has the opportunity to talk extensively in the target language.

The previously explored strategies develop speaking skills in different ways. Teacher should select the appropriate activities for their pupils.

\section{Related Studies}

Murad (2009) investigated the effectiveness of a task-based language teaching (TBLT) program in developing the speaking skills of a Palestinian secondary students and their attitudes towards English. The instruments were: A pre-post speaking test and a TBLT program and an attitudinal questionnaire. The results of the study revealed that the TBLT program enhanced significantly the speaking skills of the students and positively affected their attitudes towards English. Also, the TBLT program improved the girls' speaking skills more than the boys in the experimental group. 
Haroun (2012) investigated the effectiveness of teaching digital stories on improving EFL primary pupils' speaking skill. The researcher depended in her study on applying eleven digital stories downloaded from the British council website, the digital stories were included in a complete project program including the objectives, activities, timing and assessment of each digital story. The results of the study revealed that digital stories proved to be a very interesting tool of study for YLs, as it provided a funny atmosphere. Pupils were very enthusiastic to learn by computers and they were concentrating all the time.

Ebraheem (2016) investigated the effect of the proposed program which is based on beyond constructivism paradigm on developing the prep students' English reading and writing proficiency. In this study, the experimental group received the instruction the proposed program. On the other hand the control group received regular instructions. The results of that study were in favor of the experimental group in their high scores in the post test rather than the control group. This study shows that technology is a necessary component and should be integrated into practice in language education, not just to enhance for extend existing practice but to change practice.

Ali, (2016) investigated the effect of using knowledge navigation on developing prep students' English reading and writing skills. The findings of this study can be summed up in the following :First, the use of knowledge navigation enhances EFL students reading skills. Second, the use of knowledge navigation enhances EFL students writing skills. Third, the use of knowledge navigation increases students' motivation toward learning. Finally, the use of knowledge navigation helps teachers draw a detailed picture about their students' strengths and needs.

\section{The Statement of the Problem}

The research problem was stated as follows :

Based on the literature, the researcher's experience as a teacher of English, and the results of the pilot study, it was clear that 6th grade primary pupils' are in dire need to improve their EFL speaking skills. Thus, there is a need for a beyond constructivism based-approach which may help to develop pupils' EFl speaking skills.

Consequently, the current study investigated the effect of using a program based on beyond constructivism paradigm in developing 6th grade Primary pupils' English speaking skills.

\section{Questions of the study:}


question:

The present study attempted to find an answer to the following main

- What is the effectiveness of using a program based on beyond constructivism paradigm in developing 6th grade primary pupils' EFL speaking skills?

For research purposes, the following sub-questions were derived from this main question:

- What are the EFL speaking skills necessary for the 6th grade primary pupils?

- What are the features of a program based on Beyond Constructivism Paradigm that is expected to develop 6th grade primary pupils' speaking skills?

- To what extent is the proposed program will be effective in developing 6th grade primary pupils' speaking skills?

\section{Purpose of the study:}

The current study aimed at:

- Improving the speaking skills of sixth grade primary school pupils.

- Identifying the features of the proposed program which is based on beyond constructivism paradigm.

- Identifying the effect of using beyond constructivism based program on developing sixth grade primary pupils' speaking skills.

\section{Hypotheses}

\section{The following hypotheses were verified:}

- There is a statistically significant difference between the mean scores of the experimental group pupils and those of the control group pupils on the speaking post -test in favor of the experimental group pupils.

- There is a statistically significant difference between the mean scores of the experimental group pupils on the pre and post administrations of the Speaking Test in favor of the post-one.

\section{Significance of the Study:}

The study could be considered significant as it would contribute to:

1. Improving primary school pupils' EFL speaking skills.

2.Helping EFL teacher with modern techniques to enhance the speaking skills.

3. Promoting teachers' understanding of knowledge navigation.

4.Directing teachers' attention to use technology in teaching English.

5.Directing the attention of specialists in developing and designing curricula, especially when using technology.

6. As the program fostering interaction and teamwork among pupils. 


\section{Methods}

\section{Participants:}

The participants of the study were a group of 6th grade primary stage pupils. Those pupils were selected randomly from Official Language Schools in Elsinbillawin, Dakahlia Governorate during the First term of the academic year 2018. They were assigned to two groups an experimental group and a control one. Each group consisted of 35 pupils.

\section{Setting}

The experiment took place in Elsinbillawin Official Language Schools, Al-Dakahlia Governorate. Two classes of sixth grade pupils were selected for experimentation during the first semester of the 2018/2019 academic year for the period of 6 weeks during October and November.

\section{Instruments of the Study}

Two instruments were designed by the researcher and used in this study, namely;

- An EFL Speaking Skills Checklist to determine the most important EFL speaking skills necessary for the 6th grade primary pupils.

- A Speaking Skills Test for assessing the performance of the 6th grade primary stage pupils with a scoring rubric to provide clear and accurate standards for scoring the test.

\section{Definition of Terms}

\section{Skill}

The following are the definitions of the major terms used in the study

According to Kim (2008), a skill is defined as "the ability to produce solutions in some problem domain. It is also the familiar knowledge of any art or science, united with readiness and dexterity in execution or performance in the application of art or science to practical purposes."(p. 3565)

\section{Speaking}

There are various definitions of the speaking skill:

- Remson (2007) defines speaking as "a network of movement and knowledge that allows individuals to communicate with each other by talking and listening."(p.75)

- Luoma (2004) define speaking as "an interactive process of constructing meaning that involves producing, receiving and processing information. Its form and meaning are dependent on the context in which it occurs, including the participants themselves, the physical environment, and the purposes for speaking." (p.9) 
- According to Fulcher, (2003), "Speaking is one of language skills which is very important to be mastered by pupils in order to be good communicators. Speaking is the verbal usage of language to communicate with others." (p.23)

- The researcher defines Speaking is defined here as the ability to carry out communicative tasks, sharing thoughts, ideas, attitudes with other using appropriate pronunciation, fluency, grammar and vocabulary.

\section{Paradigm shift}

- Lombrozo (2016) defined a paradigm shift as an important change that happens when the regular way of thinking about or doing something is changed by a new and different way.(p.23)

- Paradigm shift was operationally defined for the purpose of this study as a new model envisaged for the future that make fundamental change.

\section{Beyond Constructivism}

- Beyond constructivism paradigm is defined as a learning paradigm which is starting to shift beyond the changes experienced in the 20th century in terms of the role of teaching and learning. While the role of the teacher first shifted from "teaching" to "learning facilitation", the latest shift is towards "facilitated and supported enquiry"( Brown 2006.(

- Frielick (2004) defined beyond constructivism as an ecological approach to e-learning that goes beyond the comfort zone of constructivism and examine the limitations of e-learning for enabling deep approaches to student learning (p.329).

- Beyond Constructivism Paradigm was operationally defined as a theory, or model that is the path to the future. Move from constructivism to navigationism; from knowledge creation to knowledge navigation and go beyond it. It is a change of the past methods that goes beyond constructivism.

\section{Result and discussion}

\section{Testing the First Hypothesis}

The first hypothesis stated that: "There is a statistically significant difference between the mean scores of the experimental group pupils and those of the control group pupils on the Speaking Skills post -test in favor of the experimental group pupils".

The t-test for independent samples was used to test the first hypothesis, which addressed the difference between the experimental and control groups on the post administration of the Speaking Skills test. Table (7) compares the mean scores of the experimental and control groups of 
each speaking sub-skill on the post administration of the Speaking Skills test.

Table (7) t-test values for the difference between the control and experimental groups on the post- administration of the Speaking Skills

test

\begin{tabular}{|c|c|c|c|c|c|c|c|}
\hline Sign. & df & $\mathbf{t}$ & $\begin{array}{c}\text { Std. } \\
\text { Deviation }\end{array}$ & Mean & $\mathbf{N}$ & group & skills \\
\hline 0.05 & 68 & 2.611 & .69209 & 4.1429 & 35 & post control & \multirow[t]{2}{*}{ Pronunciation } \\
\hline & & & .93755 & 4.6571 & 35 & $\begin{array}{c}\text { post } \\
\text { experimental }\end{array}$ & \\
\hline 0.01 & 68 & 4.369 & .84316 & 3.6286 & 35 & post control & \multirow[t]{2}{*}{ Vocabulary } \\
\hline & & & .85307 & 4.5143 & 35 & $\begin{array}{c}\text { post } \\
\text { experimental }\end{array}$ & \\
\hline 0.01 & 68 & 9.112 & .78857 & 4.2857 & 35 & post control & \multirow[t]{2}{*}{ Grammar } \\
\hline & & & .91210 & 6.1429 & 35 & $\begin{array}{c}\text { post } \\
\text { experimental }\end{array}$ & \\
\hline 0.01 & 68 & 3.093 & .61220 & 3.5143 & 35 & post control & \multirow[t]{2}{*}{ fluency } \\
\hline & & & 1.09774 & 4.1714 & 35 & $\begin{array}{c}\text { post } \\
\text { experimental }\end{array}$ & \\
\hline 0.01 & 68 & 4.137 & .78000 & 3.7429 & 35 & post control & \multirow[t]{2}{*}{ Comprehensibility } \\
\hline & & & .94558 & 4.6000 & 35 & $\begin{array}{c}\text { post } \\
\text { experimental }\end{array}$ & \\
\hline 0.01 & 68 & 8.206 & 2.19319 & 19.3143 & 35 & post control & \multirow[t]{2}{*}{ total } \\
\hline & & & 2.64988 & 24.0857 & 35 & $\begin{array}{c}\text { post } \\
\text { experimental }\end{array}$ & \\
\hline
\end{tabular}

Statistical results in table (7) indicate that the experimental group mean scores of each speaking skill on the post administration of the test increased. These results indicate that the higher means were obtained for the experimental group as $t$-value of these sub-skills ranged between 4.1714 and 6.1429.

The $t$-test value of the overall speaking posttest was 8.206, and it was significant at 0.01 level. This result indicates that the experimental group outperformed the control group on the Speaking Skills posttest due to using the beyond-constructivism paradigm based program.

\section{Estimating the effect size ( $\boldsymbol{\eta} 2)$ :}

Eta Square ( $\eta 2)$ was used in order to estimate the effect size of the experimental treatment. Table (8) shows the results. 
Table (8): Value of ( $\eta 2)$ and Effect Size Level

\begin{tabular}{|c|c|c|c|c|}
\hline $\begin{array}{c}\text { Level of } \\
\text { Effect size }\end{array}$ & $\begin{array}{c}\text { Value of Eta }- \\
\text { Square }(\boldsymbol{\eta} 2)^{*}\end{array}$ & $\mathbf{t}$ & Skills & Independent Variable \\
\hline Medium & 0.09 & 2.611 & Pronunciation & \multirow{2}{*}{$\begin{array}{c}\text { Beyond-Constructivisim } \\
\text { paradigm based program }\end{array}$} \\
\cline { 1 - 4 } High & 0.22 & 4.369 & vocabulary & \\
\hline High & 0.55 & 9.112 & grammar & \\
\cline { 1 - 4 } Medium & 0.12 & 3.093 & fluency & \\
\cline { 1 - 3 } High & 0.20 & 4.137 & comprehensibility \\
\cline { 1 - 3 } High & 0.50 & 8.206 & total & \\
\hline
\end{tabular}

It must be noted here that the effect size is calculated based on the difference between the pre-test and post test scores of the experimental group.

Testing the Second Hypothesis

The second hypothesis stated that: " There is a statistically significant difference between the mean scores of the experimental group pupils on the pre and post administrations of the Speaking Skills test in favor of the postone".

The $t$-test for paired samples was used to test the second hypothesis in order to investigate if there was any statistically significant difference between the mean scores of the experimental group pupils on the Speaking Skills pre- and post-test because of the administration of the experimental treatment. Following are the results of the $t$-test comparing the mean score of the pupils in the experimental group on the pre/post overall speaking skills test.

Table (9) t-test values for the difference between mean scores of both pre and posttest of experimental group on the pre-and post

Speaking Skills test

\begin{tabular}{|c|c|c|c|c|c|c|c|}
\hline sign & $d f$ & $t$ & $\begin{array}{c}\text { Std. } \\
\text { Deviation }\end{array}$ & Mean & $N$ & group & skills \\
\hline \multirow[t]{2}{*}{0.01} & 34 & \multirow[b]{2}{*}{3.636} & .72529 & 4.0571 & 35 & Pre experimental & \multirow[b]{2}{*}{ Pronunciation } \\
\hline & & & .93755 & 4.6571 & 35 & Post experimental & \\
\hline \multirow[t]{2}{*}{0.01} & 34 & \multirow[b]{2}{*}{4.859} & .87735 & 3.6286 & 35 & Pre experimental & \multirow[t]{2}{*}{ vocabulary } \\
\hline & & & .85307 & 4.5143 & 35 & Post experimental & \\
\hline 0.01 & 34 & \multirow[b]{2}{*}{13.00} & .78857 & 4.2857 & 35 & Pre experimental & \multirow[t]{2}{*}{ Grammar } \\
\hline & & & .91210 & 6.1429 & 35 & Post experimental & \\
\hline \multirow[t]{2}{*}{0.01} & 34 & \multirow[b]{2}{*}{3.757} & .55307 & 3.4000 & 35 & Pre experimental & \multirow[t]{2}{*}{ Fluency } \\
\hline & & & 1.09774 & 4.1714 & 35 & Post experimental & \\
\hline 0.01 & 34 & \multirow[b]{2}{*}{3.667} & .79600 & 3.8857 & 35 & Pre experimental & \multirow[t]{2}{*}{ Comprehensibility } \\
\hline & & & .94558 & 4.6000 & 35 & Post experimental & \\
\hline \multirow[t]{2}{*}{0.01} & 34 & \multirow[b]{2}{*}{9.156} & 2.59346 & 19.2571 & 35 & Pre experimental & \multirow[t]{2}{*}{ total } \\
\hline & & & 2.64988 & 24.0857 & 35 & Post experimental & \\
\hline
\end{tabular}


Results in table (9) indicate that the mean scores of the pupils on the pre-total Speaking Skills test was (19.2571), while their mean score on the post-total Speaking Skills test was (24.0857). These results indicate that the high mean was obtained for the post-test results. So, it can also be noticed that $\mathrm{t}$ - value for the overall speaking skills test was 9.156. This value was significant at 0.01 level in favor of the post administration of the speaking skills test.

Thus, the results of the $t$-test verified the second hypothesis. It showed that there was a statistically significant difference between the mean scores of the experimental group pupils on the pre and post speaking skills test in the overall speaking skills in favor of the post administration. This difference was significant at the level of 0.01 .

Table (9) also shows more details about each sub-skill of the speaking skills. The statistics indicate that the experimental group pupils' mean score of each Speaking Skill on the post administration of the test increased. These results implied that the high means were obtained for the post administration of the speaking skills test. Results in table (9) also indicate that the mean score of the sub-skills increased. The $t$-value of each sub-skill of the speaking skills posttest ranged between 4.1714 and 6.1429 .

The overall result of the $t$-test values of the experimental group participants' pre-and post-test was 9.156, and it was significant at 0.01 level in favor of the post administration of the Speaking Skills test due to using the beyond constructivisim paradigm based program.

\section{Estimating the effect size ( $\boldsymbol{\eta} 2)$ :}

Eta Square $(\eta 2)$ was used in order to estimate the effect size of the experimental treatment. Table (10) shows the results.

\section{Table (10): Value of ( $\eta 2)$ and Effect Size Level}

\begin{tabular}{|c|c|c|c|c|}
\hline $\begin{array}{l}\text { Level of } \\
\text { Effect size }\end{array}$ & $\begin{array}{l}\text { Value of Eta- } \\
\text { Square }(\eta 2)^{*}\end{array}$ & $\bar{t}$ & Skills & Independent Variable \\
\hline High & 0.28 & 3.636 & Pronunciation & \multirow{6}{*}{$\begin{array}{c}\text { Beyond-Constructivisim } \\
\text { paradigm based program }\end{array}$} \\
\hline High & 0.41 & 4.859 & vocabulary & \\
\hline High & 0.83 & 13.00 & grammar & \\
\hline High & 0.29 & 3.757 & fluency & \\
\hline High & 0.28 & 3.667 & comprehensibility & \\
\hline High & 0.50 & 9.156 & total & \\
\hline
\end{tabular}

To calculate the effect size of the experimental treatment, eta square ( $\eta 2)$ was employed. 
According to table (10), the effect size of the independent variable (Beyond-Constructivisim paradigm based program) on the dependent variable (speaking skills) can be discussed as follows:

- Pronunciation: $28 \%$ of the total variance in the pronunciation skill can be attributed to the proposed program.

- Vocabulary: $41 \%$ of the total variance in the pronunciation skill can be attributed to the proposed program.

- Grammatical skills: $83 \%$ of the total variance in the pronunciation skill can be attributed to the proposed program

- Fluency: $29 \%$ of the total variance in the pronunciation skill can be attributed to the proposed program

- Comprehensibility: $28 \%$ of the total variance in the pronunciation skill can be attributed to the proposed program

The results also show that $71 \%$ of the total variance on the Speaking Skill test could be attributed to the proposed beyond constructivism- based program. According to Cohen's Standards, this is a high indicator of the effect of the treatment on promoting the students' speaking skills. It is obvious from the previous table that the effect of the program on the development of the Speaking Skills was significant, as it is clear that the influence in the total degree reached $71 \%$.

The significant difference between the pre and post administrations shown in table (4) and the effect size results shown in table (10) support the positive effect of the proposed treatment on promoting the participants' speaking skills; and this effect was in favor of the post administration. Consequently, the second hypothesis of the study was accepted.

\section{Discussion of the results:}

The current study was designed to investigate the effectiveness of the Beyond-Constructivism based program in developing EFL speaking skills among primary school pupils. The results of the study indicated that the proposed program was highly effective in developing the pupils' levels of the Speaking Skills on the pre-posttest compared to the posttest results.

These results are in line with the results reported by Haroun (2012), Elsayed (2014), Ebraheem (2016), Ali (2016), Roshdy (2018), Eltabakh (2018), ElBahnasy (2019) and Ramadan (2019).

\section{The results might be due to the following reasons:}

- The educational site that was designed by the researcher included lessons and activities with different tools and actions to help the pupils learn in a meaningful, peaceful, positive and enjoyable atmosphere. 
- The proposed beyond constructivism based program used materials that raised pupils' motivation, interest, and providing pupils with opportunity for active participation. The videos and the tracks helped them to understand the lessons.

- The nature of beyond constructivism based program which includes navigation, evaluating and communication. These features may have helped the pupils shift from one activity to another and competing tasks without losing time.

- The beyond constructivism based program provides the pupils with the activities needed for developing EFL speaking skills.

- The program also provides the sixth grade pupils with a new opportunity to engage in conversations, to prepare a talk and share with the classmates.

- The suggested program concentrates on developing the sixth grade pupils' EFL speaking skills. Besides, it may have helped in improving other language skills as listening.

- The researcher explored various tools in speaking activities that helped the pupils to develop their EFL speaking skills. The researcher used various games and activities which depended mainly on authentic materials to enrich pupils' learning in peaceful enjoyable environment.

- The researcher designed an evaluation form for the sessions. Pupils were informed that they would be assessed according to their participation and answering short online forms and submit their answers to record their answers and get feedback. The forms were prepared by the researcher.

The previous results and discussion led the researcher to conclude that sixth primary grade pupils' EFL speaking skills have been improved. The experimental treatment (Beyond-Constructivism Paradigm Based Program) was effective in improving pupils' speaking skills. Thus, the present chapter led to the conclusion that the proposed program was effective in improving primary pupils' EFL speaking skills.

\section{Conclusions}

With reference to the results of the current study, the following points were concluded:

- The present study provided evidence for the effectiveness of using the beyond constructivism paradigm in enhancing EFL learners' Speaking Skills. The study results came in accordance with some previously mentioned studies. 
- The experimental group performance improved at the end of the treatment, and it was much higher than that of the control group.

- The mean score of the experimental group was higher than that of the control group on each sub-skill of the post Speaking Skills test.

- The present study highlighted the possibility of integrating learning strategies within a beyond-constructivism model to enhance Speaking.

\section{Recommendations of the Study}

Based on the results and conclusions of the current study, the following recommendations were suggested:

- The proposed beyond-constructivism paradigm based program is recommended to be used by EFL teachers as a framework for developing speaking skills and it can be adapted by curriculum designers to develop other language skills.

- The proposed program is recommended to be integrated in the "Speaking Course" that learners may study or participate in and it should receive more attention from the curriculum designers.

- New techniques for enhancing speaking should be explored and exploited, so that language learners will easily make their way to their proficiency goals.

- learners ought to adopt technology in teaching and learning in order to improve their levels in all academic fields.

- Speaking skills should receive more attention so as to be enhanced especially at the primary stage.

\section{References}

Alexander, R. (2008). Towards dialogic teaching: Rethinking classroom talk (4th ed.). Cambridge: Dialogos.

Ali, R. (2016). The Effect of a program based on knowledge navigation on Developing EFL Reading and writing skills for prep Students. Ph.D. Faculty of Edcation, Ain Shams University, Egypt.

Barber, M.; Donnelly, K. \& Rizvi, S. (2013). An avalanche is coming: Higher education and the revolution ahead. The Institute for Public Policy Research. Harvard University. London .Retrieved from : http://www.ippr.org

Bell, F. (2011). Connectivism: Its Place in Theory-Informed Research and Innovation in Technology-Enabled Learning . International Review of Research in Open and Distance Learning, 12 (3 ) 99-118.

Blake, R. (2016). Technology and the four skills. Language Learning \&Technology, 20 (2), 129-142, University of California. Retrieved from: http://lit.msu.edu 
Brown, T. H. (2006) . Beyond constructivism: Navigationism in the knowledge era. On the Horizon, 3(14). Emerald Group Publishing limited, Bradford, Brown , T. \& Mbati , L. (2015). Mobile Learning: Moving Past the Myths and Embracing the Opportunities. The international Review of research in open and distributed learning, 16 UK. (2). Retrived form : http://www.irrodl.org

Cunningham, D.J. (1991), "Assessing constructions and constructing assessments", Educational Technology. 5(31). p. 13-17.

Ebraheem, S. (2016). The effect of using a program based on beyond constructivism paradigm on developing prep students' English reading and writing proficiency . A Ph.D. Dissertation, Ain Shams University, Egypt.

Erin, R. (2017). The Importance of Oral Language for Literacy Success. GrapeSEED US.

Grubar, M., J. (2005). Developing Listening and Speaking Skills: Practical Ways to Implement the Standards with the"Oxford Latin Course". The Classical Journal, The Classical Association of the Middle West and South, 101(1),

Haroun, A. M. (2012). The Effectiveness of Teaching Digital Stories in Developing EFL Primary Pupils' Speaking Skill. MA. Thesis. Ain Shams university, Egypt.

Hayriye, K. (2006). Teaching speaking Activities to promote speaking in a second language. University of Nevada. The Internet TESL Journal, XII (11).

Humes, L. R. (2013). The Need for New Paradigms in Education. IMS Global Learning Consortium Series on Learning Impact. May 2013. From:

http://www.imsglobal.org/articles/SLI05-052013.pdf

Kozma, R. B. (2003). Technology and classroom practices: An international study. Journal of Research on Technology in Education, 36(1), 1-14. At: https://www.stcloudstate.edu

Mayer, R. E. (2003). Multimedia learning. Cambridge, UK: Cambridge University Press.

Murad, T. M. (2009). The Effect of Task-Based Language Teaching on Developing The Speaking skills Among The Palestinian Secondary EFL Students In Israel and their attitudes towards English. M.A. Thesis. Department of curriculum and instruction, Faculty of 
Education, Yarmouk University. Retrived from: http://asian-efljournal.com

Peters, O. (1999), "The university of the future - pedagogical perspectives". paper presented at the 19th World Conference of the International Council for Open and Distance Education, Vienna, June 19-24.

Pickering, A. (2005). Culture, Science Studies and Techno-science. unpublished Manuscript. To appear in: Tony Bennett/John Frow (eds.), Handbook of Cultural Analysis. London: SAGE.

Restak, R. M. (2003). The new brain. How the modern age is rewiring your mind. Rodale, London.

Russell, C. \& Shepherd, J. (2010). Online role-play environments for higher education. British Journal of Educational Technology, 41(6), 992-1002.

Schaeffer, I. S. Glaser, J. Meister M. \& Strubing, J. (2006). What Comes after Constructivism in Science and Technology Studies? Science, Technology \& Innovation Studies. (1). ISSN: 1861-3675.

Scott, C., L. (2015). The features of learning: What kind of learning for the $21^{\text {st }}$ century? Education research and foresight. Working papers. United Nations Educational, Scientific and Cultural Organization. Retrieved from: http://unesdoc.unesco.org

Segawitz, N. (2000). Atomicity and Attention skill in fluent performance. In . H. Riggenbach (Ed.). Perspectives of Fluency, (P:200-219). Michigan: The university of Michigan Press.

Shapiro, A., \& Niederhauser, D. (2004). Learning from hypertext: Research issues and findings. In D. H. Jonassen (Ed.), Handbook of research for education communications and technology (2nd ed., pp. 605-620). Mahwah, NJ: Erlbaum.

Turner, L. (2005). 20 Technology Skills Every Educator Should Have. Transforming Education Through Technology. Retrieved from: https://thejournal.com

Ur, P. (2006). A Course in Language Teaching: Practice and theory $\left(13^{\text {th }}\right.$ Ed.).Cambridge: Cambridge University Press.

Venezky, R.L., \& Osin, L. (1991). The intelligent design of computerassisted instruction. The mysteries of planning learning experiences. New York, Longman.

Widiastuti, R. (2008). "Teaching Speaking Through Dialogue to the Eleventh Year Student: a Case Study at SMK Muhammadiyah 1 
JATINOM. Skripsi thesis,Universitas Muhammadiyah Surakarta. Retrieved from: http://viewer.eprints.ums.ac.id/archive/etd/168.

Wright, A. (2006). Games for Language Learning, (3rd ed.). Cambridge: Cambridge University Press. https://doi.org/10.1017/CBO9780511667145. 